This is an electronic reprint of the original article. This reprint may differ from the original in pagination and typographic detail.

Author(s): Caro, Erka; Berntsen, Lisa; Lillie, Nathan; Wagner, Ines

Title: $\quad$ Posted Migration and Segregation in the European Construction Sector

Year: $\quad 2015$

Version:

Please cite the original version:

Caro, E., Berntsen, L., Lillie, N., \& Wagner, I. (2015). Posted Migration and

Segregation in the European Construction Sector. Journal of Ethnic and Migration

Studies, 41(10), 1600-1620. https://doi.org/10.1080/1369183X.2015.1015406

All material supplied via JYX is protected by copyright and other intellectual property rights, and duplication or sale of all or part of any of the repository collections is not permitted, except that material may be duplicated by you for your research use or educational purposes in electronic or print form. You must obtain permission for any other use. Electronic or print copies may not be offered, whether for sale or otherwise to anyone who is not an authorised user. 


\section{Posted Migration and Segregation in the European Construction Sector}

Worker 'posting', or temporary migration of manual workers sent by their employers to work on projects abroad has become increasingly prominent in the European construction industry. It is now normal to find groups of workers from all around Europe on construction sites, living in nearby temporary accommodations, moving on to other projects or back home when the project is complete. This article highlights the interaction between the social and spatial segregation and transnational mobility of these workers in the EU construction labour market. We argue that the work-focused and employer-dominated nature of the posted workers' social world abroad contributes to their segregation from host societies, and reinforces a nationally based labour market segmentation of the European construction labour market. This is because posted workers do not have the same opportunity or interest to build structural resources in host societies and workplaces as more permanent migrants.

KEYWORDS: labour migration, posted workers, temporary migration, segregation, labour market segmentation 


\section{Introduction}

Since the accession of the eastern European countries to the EU, Europe has been undergoing a new wave of temporary and circular labour migration. This is due to wage differences between the new and old member states, but is also the outcome of EU policies which have made cross border movements within the EU less complicated. In the construction industry, much of this migration is occurring in the form of "posted work", i.e. when workers are "posted" by employers to work abroad. Posted workers move abroad as part of a dependent work relationship with an employer from their home country or from another sending country, rather than moving as individuals to take up or seek a job in the host country. Although originally intended as a framework for firms to send employees abroad for short periods to perform specific tasks, it has become one of the formulations employers use to avoid labour regulation and employ low wage migrants in precarious jobs (Bosch et al. 2013: 174-175; Cremers 2010). Partly as a result of the growth of posting, it is now common to find groups of workers of various nationalities living and working at and around large construction sites in Western Europe. They are there for a short duration, and then return home, or move on to other construction sites. They are flexible, contingent and usually poorly paid, and accept their secondary position in western European job markets because of poor employment prospects at home, or because their wages are high relative to wages in their home job market. The posting issue has risen to political salience because of the competitive threat posed by posted workers and the subcontractors and work agencies which employ them to native workers and firms in high wage countries, and most of the academic work on the topic to date has focused on this aspect (c.f. Menz 2010; Lillie and Greer 2007; Felini, Ferro and Fullin 2007; Cremers 2010, 2013).

There has been less research, however, on the subjective experience of posted workers, as a distinct form of economic migrant, and on how they encounter their host country surroundings. This article extends research on the industrial relations implications of posting in a different direction, to show how employer-arranged posting of workers on large construction sites leads to the social and spatial segregation of migrants from host surroundings. Based on interviews exploring the experiences and perceptions of posted migrant workers on large construction sites in three host countries (the Netherlands, Germany and Finland) we argue that posted migrants' position in host labour markets and societies is characterized by spatial and social segregation and strong home country orientation which impacts their working and private lives abroad. This ephemeral, disconnected and dependent character of posted migration ensures that posted migrants experience neither the integration process typical of established immigrant communities, nor the multi-sited embeddedness of transnational migrants. The social spaces where migrants reside have a logic of their own, which discourages contact between workers of different firms and nationalities and between workers and the host society. These facts have implications not only for the quality of the posted workers' working and social lives, but also suggest that they cannot build up the same economic and social resources in host societies and workplaces as more permanent migrant communities do.

\section{Posted Workers as a Specific Form of Contemporary EU Labour Migration}

Cross-border movements within the EU have become less complicated due to European integration and European regulatory frameworks promoting temporary migration. "Posting" as a form of intra-EU labour mobility has a long history, going back in some form to the 1957 Treaty of Rome. The meaning of the free movement of workers, and of posting have shifted 
with time, becoming less state-managed and more driven by the autonomous actions of workers and firms - i.e. less like a managed migration between national labour markets and more like a pan-EU labour market (Arnholz 2014). While earlier waves of labour migration, for example into Germany in the 1990s, bore some similarities to the present wave, they could still regarded in the frame of state-managed labour migration, justified because of skills shortages, the need to provide political asylum or some other political goal of the state (Rudolf 1996; Wilpert 1998). In the current round of migration individual states do little to shape the migration process directly. The EUs constitutionally based freedom of movement for labour and services provides the basis of the regulatory framework, limiting states' freedom of action in excluding EU nationals. As a result flows have a more transnational, circular and temporary character than those in the past, shaped quite directly by labour market opportunities (Engbersen et al., 2013; Meardi 2007). Migration flows since the accession of Eastern European countries to the EU and the 2008 economic crisis, have largely been dominated by East-West and to a lesser extent South-North flows. These. While more classic patterns of seasonal and settlement migration persist, migration patterns have become more fragmented and undefined, less network-driven and more employer arranged, with migrants casually moving between multiple countries for work (Engbersen et al., 2013). Intra-EU labour migration flows include of course many types of migrants. Posted work is one example of the ways labour migrants access European labour markets.

Posted workers share certain characteristics with transnational migrants. Transnational migrants are "immigrants whose daily lives depend on multiple and constant interconnections across international borders and whose public identities are configured in relationship to more than one nation-state" (Glick Schiller et al. 1995: 48). For example, a large share of migrants from Mexico to the United States could be described as transnational migrants. Transnational migrants sometimes settle and become incorporated, to a greater or lesser degree, into the society of the countries where they work but remain simultaneously embedded in their home country, as has occurred in the US-Mexico case (Roberts et al. 1999). In contrast, posted workers reside for limited periods in one or multiple countries, their migration process is employer-arranged and they often refrain from embedding themselves to any significant extent in other countries but their home country.

For this analysis, the important delineating feature of posted migration is the organizational context in which workers move between countries. In comparison with transnational migrants who tend to move within specific social structures/networks and migrant communities (see Massey et al., 1993), posted migration is employer-arranged so that contact with the host society is mediated via the sending country employer. The moving arrangements for their workers, usually extends to paying for travel, board and lodging specific to the posting. Posted workers' approach to the transnational labour market is individual and not closely related to host country ties (Author B, 2014). Although posted workers are often "alone movers," in that their migration process is embedded in employer networks rather than social networks, this does not necessarily mean they move alone; they often move together with groups of similarly isolated colleagues.

We use the notion of segregation, from Berry's acculturation framework (1997), to describe the situation of posted migrants who are embedded in groups of co-nationals who move in a transnational labour market, but have only limited interactions with host society. In Berry's framework, segregation is the opposite of integration, when workers do interact and become embedded in host society. Academic literature has widely addressed the contested nature of the integration concept, specifically the complexity of its socio-economic, legal, cultural and 
political dimensions (e.g. Phillips, 2010). Moreover, the relation between the multiple dimensions of integration and segregation, especially of residential segregation, is unclear (Musterd, 2003; Bolt et al., 1998). Instead of engaging with the segregation/integration debate, we explore the socio-spatial segregation of posted workers in a host society, as integration on any of these multiple dimensions is mostly irrelevant for posted workers. This is because posted workers, by definition, do not pass into local labour markets. Therefore, we build in this paper upon a definition of segregation that emphasizes the social distance and social interaction among posted workers and between posted workers and other groups (cf. Peters and Skop, 2007). We find factors which reinforce posted workers' socio-spatial segregation and home country orientation to include: the temporary nature of posted work, the fact they do not bring families, language barriers, the employer-arranged character of their mobility, and the workplace-focus of the spaces where they reside and socialize.

Immigrants that reside longer in a new environment have more opportunities to gain new resources, and time to develop norms, values and behaviors that allow them to integrate (Berry 1997; Gordon, 1964; Alba and Nee, 2003). Personal, material, social and cultural resources accumulate over time in migrant communities (Author A, 2013), and become a form of political, social and economic capital for advancing migrants' positions in host societies. This integration mechanism is lacking among posted workers mainly because their connection with host society usually lasts for the (short) duration of their job tenure while their accommodations are located (often) in remote areas which further segregates them limiting the contacts with the host society and impeding integration.

The employer-arranged migration context entails that employers mediate posted workers' interactions with host societies. Other forms of work migrants have to worry about (for example) interacting with authorities, finding a place to live, learning the language, and setting up financial services (Datta, 2009; Spencer et al., 2007). These interactions are rendered unnecessary for posted workers, on the one hand making things easier, but on the other limiting their interaction with the host society and triggering the social segregation of posted workers. Unless posted workers themselves actively seek contact with their host surroundings, their lives remain quite disconnected, socially and spatially separated from the host society and region where they temporarily reside. Instead, employer arranged migration reinforces connections with co-nationals as posted workers from the same country often share the same work and accommodation environment. The contacts with co-nationals are reinforced further because of language barriers posted workers face. For posted workers, foreign language skills are often not a necessity, because within the workplace it usually suffices if one member of a workgroup can speak the common workplace language as work teams are oftentimes aligned on the basis of nationality. Language barriers and lack of information about the institutional structure prevents them further from establishing strong contacts with the host society (Nawyn et al, 2012)

From studies in human geography and urban studies, we know the role neighborhoods and communities play in the everyday lives of immigrants and the opportunities and constraints these create for integration in host societies (Gilmartin and Migge, 2013; Musterd, 2011; 2003; Bolt et al 2010). Transnational migrant groups are often spatially segregated; their settlements being socially excluded and hard to reach (Phillips 2010, Author A, 2013). The spatial segregation reflects migrant's adjustment difficulties (Author A, 2013) and is directly related with the social and economic integration of migrant's communities (Bolt, et al, 2010; Musterd, 2003). It is argued in the literature that spatial and social segregation from host 
societies precludes migrants' integration (Phillips 1998; van Kempen and Özüekren 1998). In the case of posted workers spatial and social segregation is the norm and they lack voice in their settlement arrangements. Their residential segregation is closely linked with the employer-arranged character of their migration. Moreover, because posted workers reside for short periods of time and are very mobile, they are not classified as targets of settlement and integration policies in the same way as more permanent migrant groups (Phillips 2010) and are left on their own managing their integration process. Integration is a complex process and it varies depending on type and characteristics of migrant groups as well as on the reactions of the institutions and the host society (Bolt et al. 2010). Similar with Bolt et al (2010) we recognize that spatial and social segregation does not always and inevitably result in lack of integration (as is often depicted in academic literature and policy discourses (p. 169)), but also depends on the individual choices and circumstances of migration.

Employer-arranged migration, and the social and physical segregation associated with it, makes it more difficult to integrate, and insure that posted workers have less immediate incentive to do so. In these conditions, posted workers tend to develop better social connections with co-nationals within the working and living spaces and have a strong home country orientation, rather than developing social contacts with their host society.

\section{Motivations to Move}

Posted construction migrants exhibit many of the same motives as other temporary labour migrants moving within the EU. Trevena (2013) distinguished three different migration motives among Polish labour migrants in the UK: target earners, career-seekers and drifters (workers who pursue goals other than professional advancement or saving up). Of the posted workers we talked to, the majority would fit the definition of 'target earners,' or workers who work abroad to achieve a certain monetary 'target,' and once this is earned, return home. Datta (2009) describes the lives of target earners in the London secondary job market; these workers arrive without a fixed idea of what sort of work they will do, and flexibly move from one job to another, within the metropolitan region. While their lives are very focused on working, earning and saving, they cope with their environment in ways which involve a high degree of learning about host society structures (Datta 2009). Similarly, Krings et al. (2013) note that many Polish workers in the Irish job market use peripheral jobs, often in construction, as a gateway to better employment in Ireland. Initially, when their culturallinguistic skills were weaker, they took whatever jobs were available, but as they learned more about the Irish labour market and how to move within it, they often moved into more stable, better paid and higher skilled employment.

Unlike other temporary labour migrants, though, posted construction workers' strategies are defined more by the pan-EU labour market of their industry and craft, and less by location. Posted workers are pushed away from home due to limited job opportunities and low remuneration, and pulled abroad by the better prospects, such as higher wage levels, and arranged and covered expenditures for travel and housing. Several interviewees mentioned countries with strong labour regulations, for example, Finland and Norway, as being particularly desirable places to work. In this context, in practice strong labour regulation means well-enforced extended collective agreements (Lillie and Greer 2007; Eldring et al. 
2012), and can be considered a strong pull factor. The arranged migration trajectory simplifies the decision-making and migration process and obviates the need to adjust to a host society (Author A, 2013). Push and pull factors, however, are generally conceived as characteristics of host and home countries/regions environments (Mahroum, 2002): for posted workers, the push factor may be a lack of opportunities, but the pull factor is a definite job offer - the host country usually has higher wages and better economic conditions, but it does not necessarily have to, because the posted worker is not necessarily looking to economic conditions generally, but foremost to the specifics of a certain job offer (Author B, 2014).

\section{Posted Work as a Regulatory Regime for Employer-Arranged Migration in Construction}

The posted work phenomenon emerged from changes in the regulatory environment of the European Union which make it easier form firms to move blue collar workers within the EU. Posting has grown most rapidly in industries with extensive subcontracting, most notably construction. In this context, it has become a systematic and large scale way for employers to (more or less legally) access cheap labour and avoid national labour laws and collective agreements (Lillie and Greer 2007). The construction labour market shapes and is shaped by the posted work phenomenon. High levels of subcontracting make for a fluid labour market. Subcontracting is used in construction to access specialized knowledge, increase flexibility, manage risk and reduce labour costs. In Finland, Germany and the Netherlands, large companies (in terms of turnover) function as main contractors or as building service providers while small and medium companies assume the role of the subcontractors, and provide the majority of the workers (Author C 2012; Bosch and Zühlke-Robinet 2003; Fellini et al. 2007). Transnational work agencies and construction subcontractors compete on costs against domestic subcontractors by bringing low-cost migrant workers to sites in high labour cost countries, and preventing them from claiming the wages and benefits demanded by domestically hired workers. Therefore, the majority of posted workers on construction sites are employed via subcontractors or employment agencies that are active within the lower levels of the contracting chains.

By sending workers abroad to provide construction services, while regulating their employment relations from their home sending country, employment relations are deterritorialised and deregulated; this is made possible by regulatory gaps which emerge in the transnational regulation of employment within the EU. The EU politics of labour mobility establishes a rights regime for workers migrating as individuals and a separate regulatory channel for workers posted by their employers. Individual labour mobility is regulated differently from posted work, because posted work falls under the free provision of services rather than free mobility of labour. The difference is that posting, firstly, invokes a different set of social protections (Dølvik and Eldring 2008). Secondly, national regulators are explicitly limited by EU law in the extent they can impose national rules on posted workers, as in a series of controversial decisions, the European Court of Justice has judged interference by national regulation as a potential impediment to the freedom of movement (Cremers 2010; 2013). ${ }^{\text {iii }}$ This enables and encourages employers to recruit transnational migrants via transnational subcontractors and work agencies, because they can employ them under (partly) home-country terms of low wage countries. ${ }^{\text {iv }}$ The distinction of whether a person is 'labeled' a posted worker or an individual migrant worker has thus stark consequences on the rights regimes of the particular worker. Legally the line between posted workers and individual migrants is that if a worker comes from another country as part of an existing dependent 
employment relationship, and does not pass into the labour market of the host country, then the worker is considered posted. However, in practice a large grey area exists, which is exploited systematically by employers seeking to arbitrage between national employment law and collective agreements (Cremers 2013).

Posting has a specific legal meaning, but because of the way it is used by employers we are more concerned with the character of the employment relationship it implies, rather than whether a specific worker posting fits the strict legal definition. Because many employers use posting contracts as a way to avoid host country regulation, the actual contractual relationship of posted workers is often vaguely defined, and only becomes specifically defined when host country regulators look closely. Some of the posting employment relationships we encountered in our research conformed to the legal definition: i.e. posting of workers with an employment relationship with the posting employer extending before and after the specific posting in question. More commonly, firms hire posted workers for a specific job; in this sense, the posting is just a convenient way to avoid host country regulation. Other times, locally hired migrant workers are (illegally) classified as posted workers in order to complicate enforcement of labour regulations by local authorities. In countries (such as the Netherlands) where employers can avoid collective employment regulations by classifying workers as self-employed, it is common to encounter bogus self-employed migrant workers who are de facto dependent posted workers. Occasionally, we found workers who were posted in an organizational sense but not a legal one. These workers were brought by an employer to work on specific projects and had their accommodation and travel arranged as if they were posted workers, but they had local work contracts and social security. Although the details of contractual arrangements were often important in terms of particular enforcement efforts, the various forms of posting define a single labour market, with the line between the various categories blurred, through ignorance, legal indeterminacy and management strategy.

In this context, nationality becomes a cleavage which segments labour markets. Labour market segmentation scholars have argued that social cleavages such as ethnic divides are used to create labour hierarchies. Bonacich (1972) distinguishes three reasons why migrant workers are cheaper than their native counterparts: lower wage expectations; lack of knowledge about wage and employment standards in host country; and absence of organization and representation of this group in the host society. While in principle these challenges can be overcome, segmentation scholars note that these sorts of barriers are integral to the construction of labour markets, with some groups facing lesser challenges, and some greater (Peck 1996). Relevant to the current inquiry is interaction between regulatory regimes and labour market structures from both the home and host country, as well as the EU framework (Author D; Author B and C), which places the posted workers at the crux of what Samers (2010) refers to as a process of "international labour market segmentation" (128). International labour market segmentation is a useful concept here, as it raises the possibility of a pan-European labour market, with not only national structures of segmentation, but also micro-level interaction and "regime competition" (Streeck 1992) between them.

In particular, we have found in our other work that the interaction between labour market regime largely results in posted workers being excluded from collective channels of worker representation (Author D and C 2014; Author B and C 2014). They are therefore 'cheaper' not only because of the lower wages but because of the exploitative practices enabled by the regulatory configuration (Author B and C 2014; Author D 2014). This has encouraged employers to create and support a segmented labour market in which the rights of posted workers are legally as well as de facto different, and more often than not lower, than those of 
native workers in the workplace. However, workers quickly learn how to operate within the labour markets where they find themselves, and try to claim their rights or pass to more protected market segments when they can (Author B 2014).

\section{Scope of Posted Work}

Overlap with the grey economy and conceptual issues about how to count posted workers make it difficult to give an accurate estimate on the exact numbers of posted workers. However, the European Commission estimates that in 2005, 0.4 percent of the EU's workingage population could be classified as posted workers (Eurofound, 2011). Employers are supposed to file A1 forms with national authorities when they post a worker, in order to exempt that worker from host country social security payments. According to the A1 forms, Finland saw 3.2 postings per thousand population in 2009 , and 4.3 per thousand in 2011 . In Germany there were 2.7 posting per thousand people in 2009 and 3.9 per thousand in 2011, and the Netherlands 4.9 in 2009 and 6.6 in 2011 (Ismeri 2012 for 2009; European Commission 2013 for 2011). EU figures clearly indicate that postings mostly occur from eastern to western European (EU15) countries, although there are significant numbers of postings which do not follow that pattern.

A1 data, however, has serious limitations; it does not specify the sector, many employers do not fill out A1 forms, and management expatriates are included, although their situation is conceptually different (Eurofound 2011). It also indicates the number of postings but not the labour market impact (i.e. a posting can be of long or short duration, and one worker might be posted multiple times). Widely used practices such as bogus self-employment, or the miscategorisation of workers also lower the recorded numbers of worker postings. Regardless of the flaws of these numbers, statistics on posted workers show their number has been increasing in Western European countries since the 2004 enlargement.

\section{Methods and Approach}

The research for this article was part of a larger project looking at posted work in Finland, Germany, the Netherlands and the UK. We draw on 70 in-depth interviews and 18 group conversations of posted workers in the Netherlands, Germany and Finland between 2011 and 2014. We spoke with Polish, Portuguese, Turkish, Italian, Serbian, Croatian, German, Romanian, Dutch, Irish, Estonian and Slovakian construction workers. In addition, expert interviews with officials from trade unions, from management, government, employer associations, and work councils were conducted. In the three countries we draw on two Finnish, two German, and two Dutch cases of large construction sites, as the prevalence of posted workers at such sites is the highest. These sites have become international, in terms of both the contractors and workers employed at them. At some sites, only the managers are natives, while at others native workers remained in certain manual jobs at some firms.

Since posted workers are generally accommodated together with coworkers, we often encountered them in group settings. Therefore, we sometimes interviewed several workers at the same time in a group conversation. The interviews and group conversations were conducted either at the workers' accommodation sites or in public places, such as cafés or restaurants. Most interviews lasted between one and two hours. Informants were asked about their work experiences, social life and activities when not at work. The interviews were conducted face-to-face and consisted of a semi-structured part, collecting socio-economic background characteristics of an informant, and an open question part, where workers could 
freely talk about their experiences. We relied on interpreters in the frequent cases where the interviewer and interviewee did not share a language. Interviews were recorded with permission of the participant(s) and transcribed verbatim afterwards, or conducted with the interviewer taking notes, in cases where the participant preferred not to be recorded. We also wrote and sometimes refer to extensive field notes about, among other things, the physical environment where posted workers live.

We refer to workers as posted workers when they are sent by their employer to work in another country. However, we do not limit ourselves to the strict legal definition of posted work, but instead use the posting concept to describe workers who migrate as part of a de facto dependent employment relationship. This definition reflects the reality of posted workers' dependence on their employers, allowing us to focus on the conditions, situations and experiences which result from that type of employment. Posted workers in this research can thus refer to legally posted workers, project-based postings, posted agency workers, or even domestic agency workers and (bogus) self employed workers, as long as they were recruited and sent from their home country (or a third country) to work abroad while their employer arranged administrative as well as physical aspects (transport, housing) of their migration process. This de facto definition can include third country nationals as posted workers as well.

\section{Construction Job Market Context}

Our interviews took place with workers at large construction sites, where there were a multiple of nationalities, sometimes as many as ten different ones. Travelling to work at such sites and being temporarily accommodated nearby was not uncommon in the past for native workers - although we saw few of those, perhaps due to their being more expensive than their foreign competition. The duration of their employment varied to great extent, from a couple of weeks, to several months to one or two years. Most were employed on temporary project-based contracts, where the employment relation between a worker and a firm lasts for (at most) the duration of a particular project. After a construction project, or segment thereof, finishes, workers usually need to look for a different project and also a new firm to employ them. Social networks, the Internet and intermediaries are the main sources on which posted workers rely to secure their employment (Author B 2014). There are many Internet forums and blogs where people exchange opinions and discuss work experiences that workers consult when considering taking up a job with a firm that they have not worked with before. Most workers returned home regularly in between their contracts and oftentimes during their contracts as well, when periods of working abroad are alternated with one or two weeks spend at home. Many workers had a family back home to support, who generally did not visit them while they are abroad. The working conditions of posted workers were characterized by long working hours and oftentimes payments below local labour standards; many also faced a lack of proper social insurance, non-payment or underpayment of overtime, unfair deductions for administrative costs, lodging or transport (Cremers, 2013). The skill level of the informants varied. Interviewees included concrete finishers, labourers, welders, pipefitters, mechanics, steel fixers, carpenters, scaffolders, crane operators, and cable pullers. The earnings varied as well, between 8 to 26 euros gross per hour. Pay hierarchies based on nationality were quite typical, but with substantial differences based on skill, location, and contingencies such as local union influence as well. It is important to note that the large construction site context is probably more isolated and independent of the local environment than smaller sites, or work sites in other industries. While we have come across similarly isolated groups of workers elsewhere, for example in meat processing (Author D, 
forthcoming), in other industries, such as distribution, there are more local workers present in the workplace, working together with the migrants (Author B, forthcoming).

\section{The Spatial Segregation of Employer Arranged Accommodation Sites}

Accommodations are generally linked to posted workers' employment on a certain site, and with a specific employer. They vary greatly in form and quality. Workers are often housed in apartments, houses or in bungalow/camping parks together with colleagues. Other times workers are accommodated in temporary containers, which they share or have to themselves. The accommodation may be in urban, industrial or rural areas. Usually employers want to accommodate workers within close distance to the workplace, but it is generally not the case, as in the dormitory labour regimes in China (Smith and Pun 2006), that workers are accommodated on (or around) the grounds of the work sites. The spatially separated accommodation arrangements for posted workers, has certain similarities with residential segregation where specific minority groups are clustered together and away from the host society (Musterd, 2003; 2011; Kawachi et al. 2003)

The living environments abroad tend to be Spartan, with only minimal efforts to customize them to produce a homey environment. They are usually devoid of personal objects and decorations, furnished with functional furniture, without personal items in the common rooms.

As we entered the house, we spotted a common room in front of us. The room was around 30 square meters. There was an old TV set, with a video-player, but it looked unused and a little dusty. The space did not contain many items (no newspapers, books, drinks, nor snacks); only ashtrays and empty beer cans were lying around. The common room looked as if the workers had just moved in, or as if they were afraid of leaving any personal belongings in the common area. (Field notes, the Netherlands, March 2011)

The way posted workers are accommodated generates a segregated, disconnected position toward the host society.

Here we feel like we are in a prison, as in a concentration camp. Many are not used to that type of life. I, for example, am used to this. I have worked for different companies, I am used to life in the field and that's what keeps me here. Otherwise I would stay 3/4 months and leave (laughs) (Portuguese pipefitter, the Netherlands, December 2011)

When I worked and lived in the area near Rotterdam, we would get out of the job and we would socialize with people. Even without knowing English, we could communicate with the Dutch. The Portuguese are that way. Here, there is nothing. This is a rural area, there is a minidisco, but it is too small. (Portuguese welder, the Netherlands, December 2011)

Whether residing in rural or urban industrial areas on the outskirts of cities, posted migrants are often housed in areas with minimal public transport, which tends to isolates them.

Employers, to varying degrees, provide amenities. Sometimes workers have to clean the accommodation themselves, other times this is arranged by the employer. Most of the time televisions are present, which do not always carry channels from the workers' home countries. Most, but not all of the accommodations have Internet connections. In smaller scale accommodations workers prepare their own food. When workers live at larger-scale accommodation sites, there is often a cafeteria where the employer provides food. Many 
workers appreciate food arrangements by their employer as it saves them time, which is at a premium due to their often intensive work schedules:

At my previous workplace, food was provided, which was a big plus for me.... in the sense of saving time....Now I finish work at 6 pm. Then we need to go shopping, by bus, so we get back here at the camp at $7.45 \mathrm{pm}$. And then we still need to cook, clean, do the dishes. So practically, I am free at $9 \mathrm{pm}$ or so... And I have to wake up at 4.45am. (Polish scaffolder, the Netherlands, June 2012)

The housing sites take up an important place in posted workers lives after work: it is where they socialize and interact with fellow posted workers.

After work we have nothing special to do, we just hang around here, nowhere to go, often we get bored but what can we do. (Italian welder, the Netherlands, May 2011)

While many might complain about a lack of entertainment and social activities, others indicate since their working days are so long (and many work six days a week), they prefer to sleep when off work. Several workers also mention that colleagues of theirs (rarely do they admit to doing this themselves) go to a nearby "red light district." Other activities include picnics or barbeques, visits to colleagues, friends and/or family or sightseeing tours to larger cities or historic towns. Some perform everyday activities together with their colleagues such as cooking, which often create a sense of community and social activity. Drinking alcohol together creates bonds between the workers. Workers create their own social bonds and leisure activities within given accommodation arrangements:

And sometimes we make a party, we prepare everything together. How a party can look like here? Well, we have the alcohol, and some appetizers and snacks. That would be it. (Polish welder, the Netherlands, March 2012)

The employer arranged and spatially separated accommodation and victualing facilities shape a particular living environment in which posted workers are embedded when abroad. This environment obviates the need to interact with locals, and is sometimes focused around minimizing the need to take care of non-work tasks. To the extent that posted workers socialize, it is usually with others of their own nationality, or from their own work group.

\section{Social Segregation between Posted Workers and the Host environment}

The temporary duration of posted workers' stay, language barriers, and lack of information about local institutional structures, mean that substantial contacts with the local population have little chance to develop. Most workers seem uninterested in developing contacts with locals, and do not have to, as their lives can take place solely in the spaces their employer and they themselves create, separated from host society. Efforts at social contacts with locals are sometimes rebuffed, reinforcing social segregation, as one worker notes:

There haven't been any big problems with Finns but they don't want to talk with Estonians, in their spare time nor at the work place. Finns are scared of the Estonians. I have tried to say 'good morning' in Finnish without any reply. Finns would rather stop talking when they hear somebody is speaking Estonian. (Estonian carpenter, Finland, April, 2014)

Most of the workers we talked to did not mention such experiences, but it does underline that for most contact with locals was often limited to short encounters in supermarkets or cafes. 
Still, local firms and entrepreneurs may (try to) benefit from the presence of posted workers in the region. We found cases where small town supermarkets near major construction sites had several Polish beer brands in their assortment to benefit from the increased clientele. A small shop owner mentioned adjusting opening times to the working rhythm of the workers accommodated across the street.

While their presence in a particular location is temporary, workers can be posted repeatedly by management over substantial periods of their lives. One worker told us that he had been working in Germany as a posted worker for a long time but due to the short-term nature of each posting, the convenience of living among fellow countrymen, and the spatial segregation from the host society he was not socially connected to the country.

He cannot speak German even though he has been working in Germany for 15 years. The cashiers in the supermarket are polish so even there he does not have to speak German. (Interview notes, Germany, March 2012)

The structure of posted workers' lives therefore discourages them from developing local connections, and encourages a continued reliance on their employers and on support networks among co-workers. Only on a few occasions did we find posted workers connecting meaningfully with the locals:

We played football and sat in chair on the streets. We went to church in order to get to know the local population and to make friends. Over the time people started to recognize us, to get to know us and then they talked to us. (Serbian electrician, Germany, October 2012)

The opportunities for establishing local connections are limited because employers usually house co-nationals together, segregating workers not only from the host society but also according to nationality. A manager of a housing site in the Netherlands explained to us that nationalities tend to stick together, especially when they are away from their home for a long period of time, because it creates hominess. This might be by preference, but is also triggered by language barriers, and cultural differences. Workers often mention, even if they have foreign language skills, that while working abroad socializing with fellow countrymen is the easiest:

In my own language is the easiest. Most of my acquaintances are Polish. (Polish pipefitter, the Netherlands, November 2011)

Workers responded differently as to how language barriers exist. Some workers said that they have no idea what the conditions of workers of other nationalities are because they cannot communicate. One Romanian worker who spoke English explained that language might be a barrier to interaction among different nationalities but not always, as sometimes English would serve as a lingua franca on the worksites:

For me it was good I knew English ... usually all those that are bosses here [in Finland]... they know English... (Rumanian carpenter, Finland, August 2011)

Although English sometimes served as the main language of communication at the work site, it did not always help workers in social life. The aforementioned carpenter working in Finland also referred to his lack of skill in Finnish as a "handicap," which impeded relations with Finnish workers. 
The social cohesion one might expect to find among migrants living and working together in such close proximity, is often lacking among posted workers, as they are grouped together only temporarily in certain work/living spaces. Strong bonds between different nationalities rarely happen due to language barriers and residential segregation. While posted workers generally do not integrate into host society, some do develop social bonds with their conational colleagues, especially when they work in the construction profession abroad for several years (Author B, 2014).

We don't hang around in groups as the Portuguese do for example. They come and sit at these tables with 8 or more people, and even add tables if needed. That is their life style. We don't do that as much, we do eat together at breakfast but with 5 people or so, not 25. But we live together [on the park in individual containers, but in one block]. We keep our doors open so that we can visit each other. (Polish cable puller, the Netherlands, June 2012)

The limited amount of cohesion between different national groups of posted workers is illustrated by the fact that most workers are accustomed to social conflicts happening once in a while. Social conflicts sometimes arise because of the situation of many men living in close proximity with limited contact with their surroundings and with their families, and with little to do when they are off work. One worker explains:

The lack of living space. I think this is the major problem. Missing your family or other situations when there is alcohol in play. (Polish pipefitter, the Netherlands, November 2011)

The specific characteristics of the spaces where posted workers reside when abroad tend to segregate workers into different national groups. As most live together with co-nationals, they rely primarily on these social contacts to get by while living abroad (Author B, 2014).

\section{Social Connections with the Home Country and Family}

Posted construction workers move alone, or together with colleagues, and rarely bring families. As a consequence their lives continue to be very interrelated with their home countries and many have specific aspirations related to their home countries. Affordable transportation has stimulated geographical mobility within and between countries, and inexpensive communication has alleviated the psychological barriers to movement. We found that posted workers usually maintain a strong connection with their families at home. This strong connection with family and home country reinforces the (lack of) integration intentions of posted workers (Kofman, 2004).

Most workers keep up with events at home by following the news on the Internet and television. The orientation and connection these workers maintain with their home country are reflected, for example, in the importance some of the Portuguese workers attach to having Portuguese television channels available. One Portuguese worker complained:

(...) a reason why many people leave [is]... we only have one Portuguese channel. We want SIC and TVI but we only have RTP international [Portuguese channels], which does not have anything. (Portuguese pipefitter, the Netherlands, December 2011) 
Communications via cheap telephone and Internet calls serve, according to Vertovec, "as a kind of social glue connecting small-scale social formations across the globe." (2004: 220). Regular cell phone and Internet contact allows workers to maintain a sense of connectivity and collectivity with their families. Through regular contact, workers abroad can still be involved in making family decisions (cf. Bonini 2011; Madianou and Miller 2011) helping them feel less dissociated from their (home) lives. One Serbian worker told us how the internet enabled him to participate, even from afar, in his daughter's development.

I have seen the first steps of my daughter via Skype. I have heard her say her first words via Skype. I see her everyday. She is almost two. I experience her growing up via Skype even though I was not there in person (Serbian electrician, Germany, October 2012)

Though the possibilities to stay in touch with their families back home are usually good, workers often express that they miss their families and being apart is difficult. Migration is an important strategy to cope with economic difficulties but at the same time it creates emotional distance between children and parents and husbands and wives (Author A, 2012). Several other workers mentioned that separations put a strain on relationships, sometimes leading to break-ups or divorces.

Well, the going back and forward, and the feelings when we are out and come home are very emotional. Every day we think about the family, but every day we have computers and every day we talk to each other. What I like about this is that we know that after some time we will make money and that life is going to be better. (Portuguese welder, the Netherlands, June 2012)

The paradox thus is that posted workers are mainly motivated to earn money to improve their lives at home, their working and living situation creates distance between them and their home environment.

\section{The Relations between Social and Labour Market Segregation}

- Our research suggests the ways workers are accommodated in host societies and kept separate from other national groups and the host society enables the continued segmentation of this workforce by slowing the process of learning about and integrating into host societies. We show that posted workers are more segregated and less predisposed to be part of the host society, learn the language and socialize, than other migrants because of the nature of their work and living arrangements. The high frequency of their cross-border mobility ensures that posted workers do not have the same opportunities or interests to build power resources in host societies and workplaces as more permanent migrants. Barriers such as long working hours, residence in remote/rural areas, language, and lack of information about institutional structure, makes integration unfeasible in the short time frames they intend to remain. Employer involvement in organizing the migration process both reflects and reinforces this tendency.

Similar to circular migrants in the study of Engbersen et al. (2013), posted migrants show weak and ephemeral ties to host country environments: the workers are focused on working, passing time and getting paid - life for them occurs elsewhere and elsewhen. Posted workers are present long enough in host societies to have an impact - months or years - but their stays are short enough that host society integration is unlikely. Employer strategies encourage this short term perspective, since it makes them less demanding and more vulnerable to 
exploitation. Furthermore, the absence of family and social life in the host country gives the posted worker extreme flexibility. Posted migrants do have a life beyond their work, and create social connections with their co-national colleagues and maintain contacts with their families and home country, but their social contacts tend to reinforce their segregation from their host country environment rather than embed them in it.

Posted migration follows particular kinds of (construction) jobs over pan-European spaces, and not the low-paid job market as a whole within the confined space of a country or city area (compare with Datta 2009). It is possible that for some posted workers at least, the hypermobility and segregation we observe could be an initial stage, to be followed by integration at a later point, as their job market overlaps sometimes with that of other temporary migrants. Indeed we have interviewed some workers who once were posted but eventually settled into the labour market of one of their host countries, and these tend to regard the posting period as one of transition, before landing better and more stable work. However, many of the workers we talked to had been working within this pan-European labour market for many years, and some seemed to be making a career of it.

Posted migration, as a distinct form of temporary circular migration, is becoming more and more widespread, and, unlike more conventional forms of migration, its effects on individuals and societies have not been widely investigated. In the migration literature there is a debate on the policy and economic impacts of temporary circular migration, with governments of both sending and receiving countries emphasizing the positive outcomes of migration, and promoting temporary circular migration as a form of development (Kapur and McHale, 2003). Similarly, posted work is explicitly promoted by EU institutions as a means to improve competitiveness and generate employment; it is made possible by opportunities for regulatory arbitrage in the European Union, which are inherent to the structure of EU regulation. Whatever the economic benefits, the growth of a socially disconnected floating workforce which has little investment in and social connection to any particular physical location or community raises social and political concerns, not the least of which is the effect on the posted workers themselves, of living and working in a semi-permanent state of segregation.

\section{References}

ALBA RICHARD and VICTOR NEE 2003 Remaking the American Mainstream: Assimilation and Contemporary Immigration. Cambridge, MA: Harvard Univ. Press.

ARNHOLZ JENS 2013 A 'legal revolution' in the European field of posting? Narratives of uncertainty, politics and extraordinary events, PhD Dissertation, Department of Sociology, University of Copenhagen.

BERRY, JOHN. W. 1997 'Immigration, Acculturation, and Adaptation', Applied Psychology: International Review, 46: 5-68. 
BIAO XIANG 2007 Global “Body Shopping”: An Indian System in the Information Technology Industry. Princeton, NJ: Princeton Univ. Press

BOLT GIDEON, BURGERS, J. AND R. KEMPEN (1998) On the Social significance of spatial location; spatial segregation and social inclusion. Netherlands Journal of Housing and the Built Environment 13(1): 83-95.

BOLT GIDEON, ÖZÜEKREN SULE.A, PHILIPS DEBORAH 2010 'Linking integration and residential segregation'. Journal of ethnic and migration studies 36(2):169-186.

BONINI, TIZIANO 2011 “The Media as 'home-making' Tools: Life Story of a Filipino Migrant in Milan”. Media, Culture \& Society 33 (6) (januari 9): 869-883.

BOSCH, G., AND ZÜHLKE-ROBINET, R. (2003) 'Germany: The labor market in the German construction industry,' in Building chaos an international comparison of deregulation in the construction industry, by Bosch, Gerhard, and Philips, Peter (eds.) (London: Routledge).

BOSCH, G., N. DANIJEL and L. NEUMANN (2013) 'Minimum wage and collective bargaining in the construction industry.' in: Grimshaw, D. (ed.) Minimum wages, pay equity, and comparative industrial relations. (London: Routledge), p. 168-193

CREMERS, JAN (2010) 'Rules on working conditions in Europe: subordinated to freedom of services?’ European Journal of Industrial Relations, 16(3): 293-306.

CREMERS, JAN (2013) "Free provision of services and cross-border labourrecruitment." Policy Studies, 34(2), 201-220.

DATTA, KAVITA 2009 'Risky Migrants?: Low-Paid Migrant Workers Coping With Financial Exclusion in London,' European Urban and Regional Studies 16(4): 331344.

DOLVIK, JAN ERIK. AND LINE ELDRING 2008 Mobility of labour from new EU states to the Nordic Region: Development Trends and Consequences. TemaNord: 537 Copenhagen, Nordic Council of Ministers.

ELDRING L, I FITZGERALD AND J ARNHOLTZ (2012) Post-accession migration in construction and trade union responses in Denmark, Norway and the UK. European Journal of Industrial Relations 18(1): 21-36.

EHRKAMP, PATRICIA. 2005. 'Placing Identities: Transnational Practices and Local Attachments of Turkish Immigrants in Germany'. Journal of Ethnic and Migration Studies, 31(2): 345-64.

ENGBERSEN, GODFRIED, LEERKES, ARJAN, GRABOWSKA-LUSINKA, IZABELA, SNEL, ERIK AND BURGERS, JACK 2013. "On the differential attachments of migrants from central and eastern Europe: A typology of labour migration" Journal of Ethnic and Migration Studies 39(6): 959-981.

EUROPEAN COMMISSION, EMPLOYMENT, SOCIAL AFFAIRS AND INCLUSION DG (2013) Posting of workers in the European Union and EFTA countries : Report on A1 portable documents issued in 2010 and 2011. 
FAVELL, ADRIAN 2008 "The new face of East-West migration in Europe" Journal of Ethnic and Migration Studies, 34(5):701-716.

FELLINI, IVANA, ANNA FERRO AND GIOVANNA FULLIN 2007 "Recruitment Processes and Labour Mobility: The Construction Industry in Europe.” Work, Employment \& Society, 21(2): 277-298.

GILMARTIN, MARY AND BETTINA MIGGE 2013 "European migrants in Ireland: Pathways to integration" European Urban and Regional Studies, doi: $0.1177 / 0969776412474583$

GLICK SCHILLER, NINA, LINDA BASCH AND CRISTINA SZANTON BLANC 1995 'From immigrant to transmigrant: Theorizing transnational migration' Anthropological Quarterly 68(1): 48-63.

GORDON, MILTON. 1964 Assimilation in American Life. New York: Oxford University Press.

Hedwig, Rudolph 1996 "The new gastarbeiter system in Germany Journal of Ethnic and Migration Studies 22(2): 287-300.

ISMERI EUROPA. 2012. Preparatory study for an impact assessment concerning the possible revision of the legislative framework on the posting of workers in the context of the provision of services, Final Report, March, Brussels: European Commission

IREK, MAŁGORZATA 2011 'The Myth of 'Weak Ties' and the Ghost of the Polish Peasant: Informal Networks of Polish Post-Transition Migrants in the UK and Germany'. Centre on Migration, Policy and Society. Working Paper No. 87. University of Oxford.

KAPUR, DEVESH AND JOHN MCHALE 2003 'Migration's New Payoff' Foreign Policy, No. 139: 48-57.

KAWACHI, ICHIRO AND LISA F. BERKMAN (2003) 'Neighborhoods and Health'. Oxford: Oxford University Press

KOFMAN ELEONOR. 2004 'Family-related migration: A critical review of European studies,' Journal of Ethnic and Migration Studies vol. 30 , no. 2 , pp. 243 - 62

LILLIE, NATHAN. AND GREER, IAN 2007 "Industrial relations, migration and neoliberal politics: the case of the European construction sector,", Politics \& Society, 35(4): 551-581.

MADIANOU, MIRCA, AND DANIEL MILLER 2011 "Mobile Phone Parenting: Reconfiguring Relationships Between Filipina Migrant Mothers and Their Left-behind Children". New Media \& Society 13 (3):457-470.

MAHROUM, SAMI, 2002 'Highly skilled globetrotters: mapping the international migration of human capital'. $R \& D$ Management, 30: 23-32. doi: 10.1111/14679310.00154 
MASSEY, DOUGLAS, ARANGO, J., HUGO, G., KOUAOUCI, A., PELLEGRINO, A., TAYLOR, J.E. 1993 "Theories of migration: a review and appraisal" Population and Development Review 19(3): 431-466.

MENZ, GEORG 2010 "Are you being served? Europeanizing and re-regulating the single market in services" Journal of European Public Policy, 17(7): 971-987.

MUSTERD, SAKO. 2003. 'Segregation and integration: a contested relationship'. Journal of Ethnic and Migration Studies, 29(4): 623-41.

MUSTERD, SAKO. 2011). "The impact of immigrant's segregation and concentration on social integration in selected European contexts". Documents d'Anàlisi Geogràfica, 51 (3), 359-380.

NAWYN S.J., GJOKAJ L., AGBENYIGA D.L., GRACE B 2012 Linguistic Isolation, Social Capital, and Immigrant Belonging Journal of Contemporary Ethnography, 41 (3), pp. 255-282.

PHILLIPS, DEBORAH. 2010. 'Minority ethnic segregation, integration and citizenship: a European pespective'. Journal of Ethnic and Migration Studies, 36(2): 209-25

PECK, JAMIE 1996 Work, Place: the social regulation of labour markets New York: Guilford Press

PETERS, P.A. AND SKOP, E.H. 2007. Socio-spatial segregation in metropolitan Lima. Journal of Latin American Geography 6(1): 149-171.

SAMMERS, MICHAEL 2010 "At the heart of 'migration management': immigration and labour markets in the European union," in Gabriel, Christina and Pellerin, Hélène Governing international labour migration: current issues, challenges and dilemmas Oxon: Routledge

SAMPSON, HELEN 2003 "Transnational drifters or hyperspace dwellers: an exploration of the lives of Filipino seafarers aboard and ashore," Ethnic and Racial Studies, 26(2): 253-277.

SAGGAR SHAMIT., WILL SOMERVILLE, ROB FORD, AND MARIA SOBOLEWSKA 2012 The impacts of migration on social cohesion and integration. Report, founded by Migration Advisory Committee.

SMITH, CHRIS, AND NGAI PUN 2006 "The dormitory labour regime in China as a site for control and resistance". The International Journal of Human Resource Management 17 (8): 1456-1470.

ROBERTS, B.R., FRANK, R. \& LOZANO-ASCENCIO, F., 1999. Transnational migrant communities and Mexican migration to the US. Ethnic and racial studies 22(2), pp.238-266.

TREVENA, PAULINA. (2013) 'Why Do Highly Educated Migrants Go For Low-Skilled Jobs? A Case Study Of Polish Graduates Working In London', In Glorius, B., Grabowska-Lusinska, I. And Rindoks, A. (Eds) Mobility In Transition: Migration Patterns After EU Enlargement. Amsterdam: Amsterdam University Press, In Press. 
VERTOVEC, STEVEN 2004 “Cheap Calls: The Social Glue of Migrant Transnationalism”. Global Networks 4 (2): 219-224.

SPENCER, SARAH., MARTIN RUHS, BRIDGET ANDERSON, AND BEN ROGALY, BEN 2007 Migrants lives beyond the workplace: The experiences of Central and East European migrants in the UK. Report funded by the Joseph Rowntree Foundation

WILPERT, CZARINA 1998 "Migration and informal work in the New Berlin: New forms of work or new sources of labour?" Journal of Ethnic and Migration Studies 24(2): 269294.

\footnotetext{
'Even though posted work does not occur only in the construction sector, for this paper we will focus on construction posted workers as our study population.

${ }^{\text {ii }}$ Worker posting has existed in the European Union for decades, but its expansion in recent years is driven by the opportunity to recruit workers from low-labour cost countries to avoid expensive regulations and high wage expectations of workers in western European countries (Bosch et al. 2013: 174-175; Author B and C 2014).

iii These so-called 'Laval Quartet' decisions are Viking, Laval and Rüffert and Commission v Luxembourg, issued between December 2007 and June 2008. The Court supported, in these four cases, the practical implementation of a 'country of origin' principle, asserting that union or government regulation of labour conditions at foreign service providers constitutes a violation of the free movement rights as set out in the 1957 Treaty of Rome.

iv The actual regulatory framework is determined by a mix of home, host, and European Union legislation.
} 